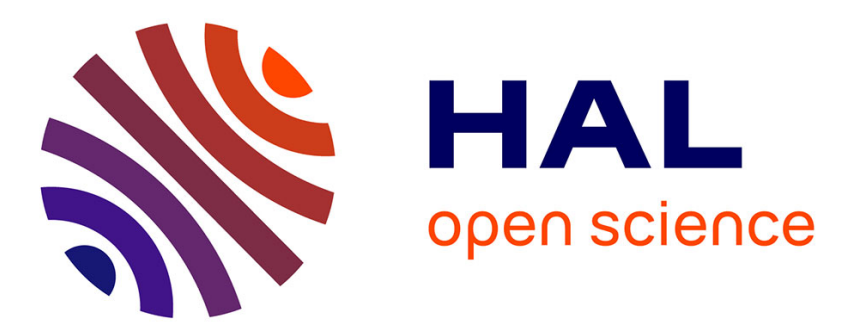

\title{
Preparation of enantiopure 1,4-amino alcohols derived from [3] ferrocenophanes: use in the asymmetric addition of diethylzinc to benzaldehyde
}

Nadège Faux, Dorothée Razafimahefa, Sophie Picart-Goetgheluck, Jacques Brocarda

\section{To cite this version:}

Nadège Faux, Dorothée Razafimahefa, Sophie Picart-Goetgheluck, Jacques Brocarda. Preparation of enantiopure 1,4-amino alcohols derived from [3]ferrocenophanes: use in the asymmetric addition of diethylzinc to benzaldehyde. Tetrahedron: Asymmetry, 2005, 16, pp.1189. 10.1016/j.tetasy.2005.01.041 . hal-00100251

\section{HAL Id: hal-00100251 \\ https://hal.science/hal-00100251}

Submitted on 26 Sep 2006

HAL is a multi-disciplinary open access archive for the deposit and dissemination of scientific research documents, whether they are published or not. The documents may come from teaching and research institutions in France or abroad, or from public or private research centers.
L'archive ouverte pluridisciplinaire HAL, est destinée au dépôt et à la diffusion de documents scientifiques de niveau recherche, publiés ou non, émanant des établissements d'enseignement et de recherche français ou étrangers, des laboratoires publics ou privés. 


\title{
Preparation of Enantiopure 1,4-Aminoalcohols Derived from [3]Ferrocenophanes; Use in the Asymmetric Addition of Diethylzinc to Benzaldehyde
}

\author{
Nadège Faux, ${ }^{\mathrm{a}}$ Dorothée Razafimahefa, ${ }^{\mathrm{b}}$ Sophie Picart-Goetgheluck ${ }^{\mathrm{a}^{\mathrm{a}}}$ and Jacques Brocard ${ }^{\mathrm{a}}$ \\ ${ }^{a}$ Laboratoire de Catalyse de Lille, Synthèse Organométallique et Catalyse, UMR CNRS 8010, ENSCL, Cité Scientifique, BP 108, F-59652 \\ Villeneuve d'Ascq Cedex, France \\ ${ }^{b}$ Laboratoire de Chimie Organométallique, Faculté des Sciences, Université d'Antananarivo BP 906, Antananarivo 101, Madagascar
}

\begin{abstract}
A series of enantiopure 1,4-aminoalcohols with a [3]ferrocenophane backbone were synthesized. Candida Rugosa lipases were used in a key step allowing the optical resolution of aminoalcohol $\left(1 S, R_{\mathrm{p}}\right)-\mathbf{1}$. Two other aminoalcohols $\left(1 S, 2 S, R_{\mathrm{p}}\right)-2$ and $\left(1 S, 2 S, R_{\mathrm{p}}\right)-\mathbf{3}$ were prepared starting from $\left(1 S, R_{\mathrm{p}}\right)-\mathbf{1}$. The new ligands have been used in the asymmetric ethylation of benzaldehyde by diethylzinc and presented good catalytic properties. One of these ligands was particularly efficient, while the yield of the catalytic test was near to $100 \%$ and the enantiomeric excess was about $80 \%$. All the ligands directed the catalytic process towards the same (1R)-1-phenylpropanol. (C) 2008 Elsevier Science. All rights reserved
\end{abstract}

\section{Introduction}

In recent years, considerable attention has been devoted to the preparation of optically active ligands. Among the latter, aminoalcohols have been applied in various enantioselective catalyzed reactions. In particular, $\mathrm{R}_{2} \mathrm{Zn}$ modified with chiral aminoalcohols shows a high ability to promote the asymmetric alkylation of prochiral aldehydes and ketones. ${ }^{1,2}$

On the other hand, since its discovery, ferrocene and its derivatives have been widely studied. ${ }^{3}$ Their substitution potential offers large possibilities for synthesis and applications. For example ferrocene compounds bearing a planar chirality ${ }^{4}$ and/or a [3] ferrocenophane backbone ${ }^{5}$ could present interesting properties. One famous application relevant to asymmetric catalysis is the alkylation of carbonyl compounds by dialkylzinc reagents. ${ }^{6}$

We have an ongoing interest in the synthesis and use of ferrocenyl compounds both as biomolecules ${ }^{7}$ and chiral auxiliaries for asymmetric catalysis. ${ }^{8}$ In this paper, we report on the lipase-catalyzed synthesis of chiral 1,4-aminoalcohols including a [3]ferrocenophane backbone and on their use in the ethylation of benzaldehyde by diethylzinc.

\section{Synthesis of enantiopure 1,4-aminoalcohols with a [3]ferrocenophane backbone}

A retrosynthetic analysis of the access to the three targeted aminoalcohols 1, 2 and $\mathbf{3}$ is given in Figure 1.

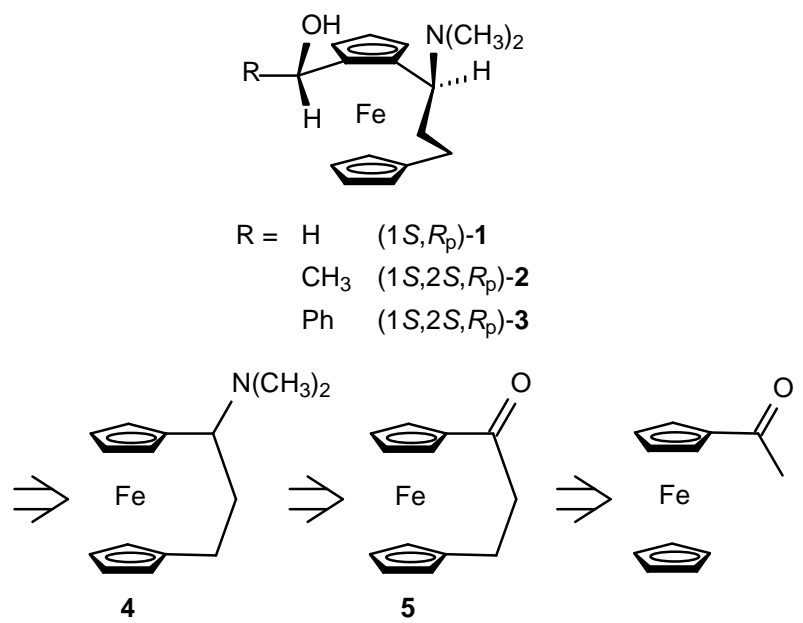

Figure 1: Strategy of synthesis of the three new aminoalcohols 1, 2 and 3 
The synthesis of optically pure 1,1'-[1-(N,N-dimethylamino)propanediyl]ferrocene 4 was describded in the literature. ${ }^{9}$ The optical resolution was attempted either by the way of a fractionated crystallization of the amine with tartric acid, ${ }^{9 \mathrm{~b}}$ but the resolution was only partial, or by the use of (S)-1-phenylethylamine as chiral auxiliary, ${ }^{9 a}$ however a step of the synthesis needs to be realized in a steel autoclave.

So we decided to develop a more efficient or easier method to reach the total optical purity via lipase-based optical resolution. Several attempts could be realized either on secondary amine 4 or on aminoalcohol 1.

Cyclic ferrocenyl ketone 5 was obtained from reaction between acetylferrocene and diethyl carbonate in the presence of NaH (Figure 2). The reaction was conducted by refluxing in dry toluene for 2 hours. ${ }^{10}$ The resulting ketoester 6 was then reduced according to Clemmensen's procedure with a concomitant hydrolysis into the carboxylic acid 7 by heating to reflux in acetic acid during 3.5 hours in the presence of a $\mathrm{Zn} / \mathrm{HgCl}_{2} / \mathrm{HCl}$ mixture. A regioselective cyclisation occurred between the two cyclopentadienyl units in the presence of trifluoroacetic acid. ${ }^{11}$ No cyclisation into ortho position was observed.

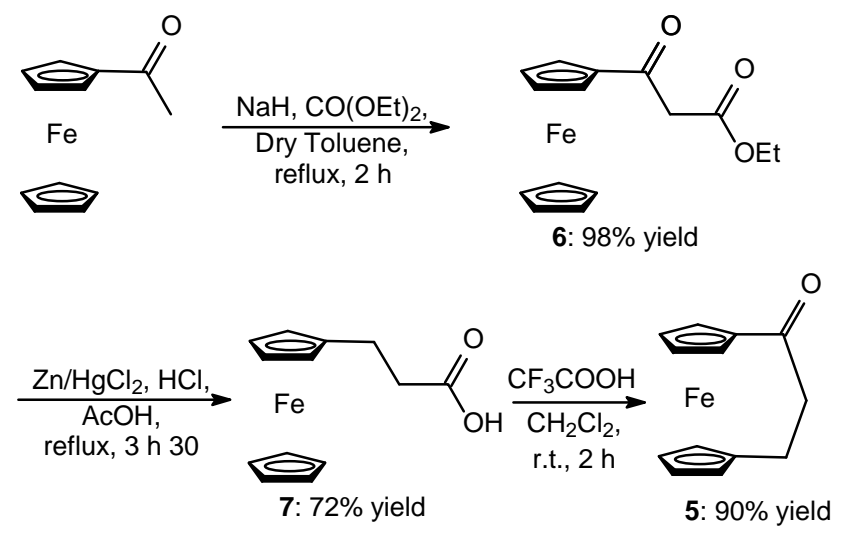

Figure 2: Synthesis of cyclic ketone 5

The next step consisted in preparing dimethylamine 4.

Methylamine was first condensed on ketone 5 in dry diethyl ether in the presence of molecular sieves $4 \AA$ (Figure 3 ). An $81 / 19$ mixture of two diastereomers of imine $\mathbf{8}$ was obtained. The proportion of each diastereomer $(Z)-\mathbf{8}$ and $(E)-\mathbf{8}$ was determined by ${ }^{1} \mathrm{H}$ NMR and NOESY analyzes: the proximity of the $\mathrm{NCH}_{3}$ group of stereoisomer $(E)-8$ to the $\mathrm{CH}_{2}$ of the cyclic alkyl chain (Figure 3) was highlighted in the NOESY spectrum. The separation of these diastereomers was not necessary (see below).

The reduction of the mixture of imines 8 by $\mathrm{NaBH}_{4}$ afforded the racemic methylamine $( \pm)-\mathbf{9}$.

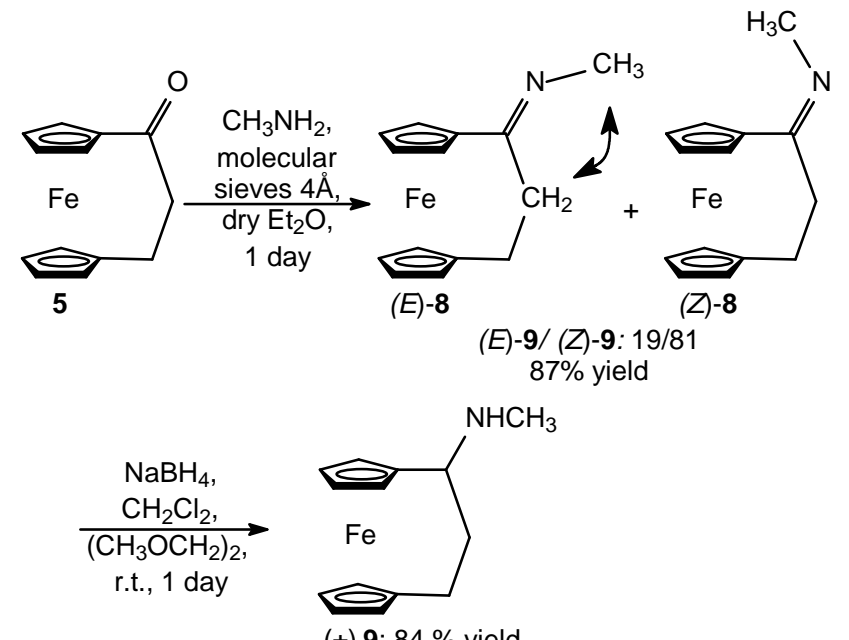

(士)-9: $84 \%$ yield

Figure 3: Synthesis of racemic secondary amine $( \pm)-\mathbf{9}$ 
Our aim was to synthesize enantiopure aminoalcohols using biocatalysis. As mentioned above, such a resolution could be attempted either on the amine $\mathbf{9}$ or on the aminoalcohol 1. Both was studied (vide infra).

Several attempts were made to resolve the racemic secondary amine $( \pm)-9 .{ }^{12}$ Unfortunately, neither the use of Candida Rugosa nor that of Candida Antartica B lipases allowed to reach a high optical purity (Figure 4).

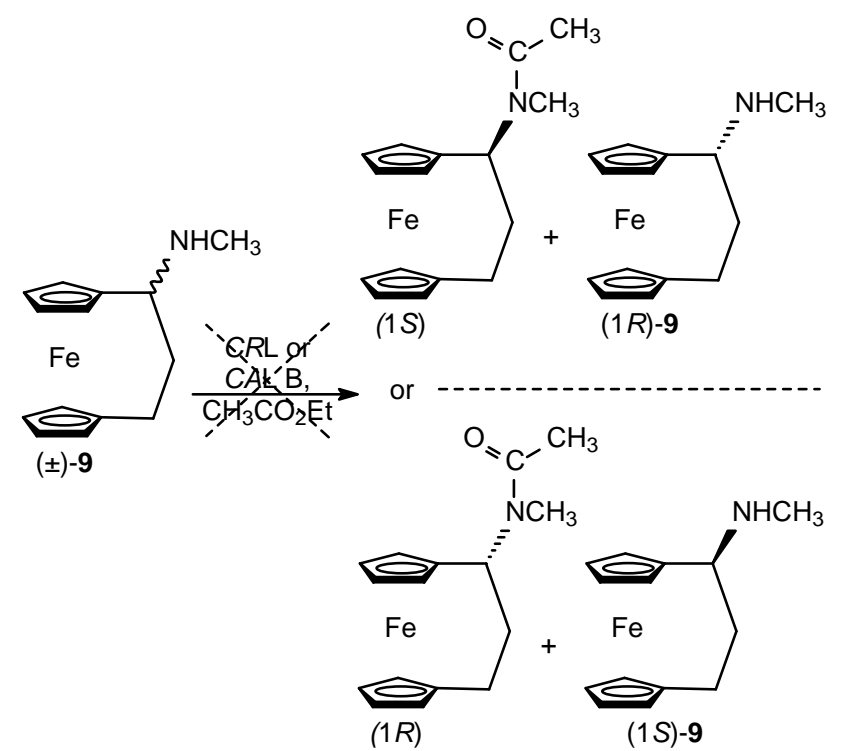

Figure 4: Attempts for optical resolution of secondary amine ( \pm -9

We next prepared the aminoalcohol $\mathbf{1}$.

This alcohol was obtained in three steps (Figure 5). The secondary amine 4 was methylated by a $\mathrm{NaBH}_{4} / \mathrm{HCHO}$ mixture in $\mathrm{H}_{2} \mathrm{O} / \mathrm{MeOH}$. The resulting dimethylamine 4 was then converted into the corresponding aminoaldehyde $( \pm)-\mathbf{1 0}$ by a deprotonation ( $n$-BuLi) / addition (DMF) sequence. The addition of $\mathrm{NaBH}_{4}$ onto aldehyde $( \pm)-\mathbf{1 0}$ produced racemic aminoalcohol $( \pm)-\mathbf{1}$.

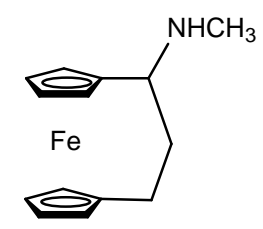

$( \pm)-9$

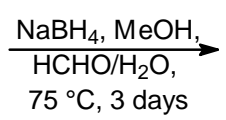

$75^{\circ} \mathrm{C}, 3$ days

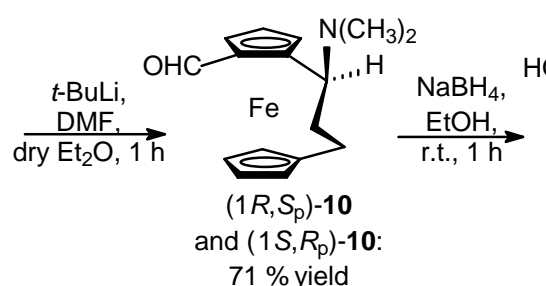

Figure 5: Synthesis of racemic $(1 R, S \mathrm{p})-\mathbf{1} /(1 S, R \mathrm{p})-\mathbf{1}^{14}$ (only one enantiomer is presented)

The regioselectivity in ortho position is attributed to the nitrogen assistance via coordination to the intermediate metalated Fc$\mathrm{Li}$ species. ${ }^{15}$ Four diastereomers could be formed. However, only two stereisomers (a couple of enantiomers) were obtained. Indeed, the blocked structure of the cyclic amine $\mathbf{4}$ hinders free rotation, which involves the location of nitrogen near one of the two ortho positions of the cyclopentadienyl ring. As a result, a single ortho lithiation occurred (Figure 6). ${ }^{9 a}$ 


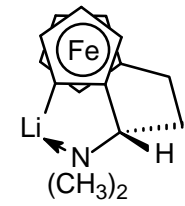

Favored species

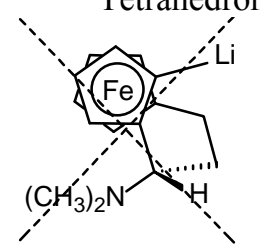

Disfavored species: no chelation

Figure 6: Stereoselective ortho lithiation of 4

The second attempt of optical resolution using biocatalysis was achieved on the aminoalcohol $\mathbf{1}$ (vide supra) by enzymatic resolution with Candida Rugosa lipases according to Nicolosi's procedure (Figure 7). ${ }^{16}$

Alcohol 1, which was not converted, and acetate $\mathbf{1 1}$ were easily separated by chromatography on silica gel. The enantiomeric excesses were determined by ${ }^{1} \mathrm{H} \mathrm{NMR}$ in $\mathrm{CDCl}_{3}$, using 1 eq. of Pirkle's alcohol. Indeed, a first analysis of the racemic

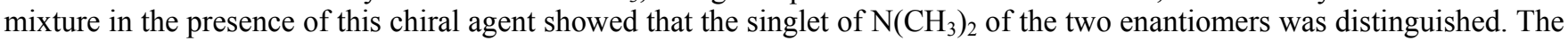
same differentiation was observed with the two doublets of the two diastereotopic protons $-\mathrm{CH}_{2}-\mathrm{O}$. The integration of each dedoubled signal allowed the determination of enantiomeric excesses. Unfortunately, the e.e. were low (about $31 \%$ and $6 \%$ respectively for acetate $\mathbf{1 1}$ and recovered alcohol $\mathbf{1}$ ).

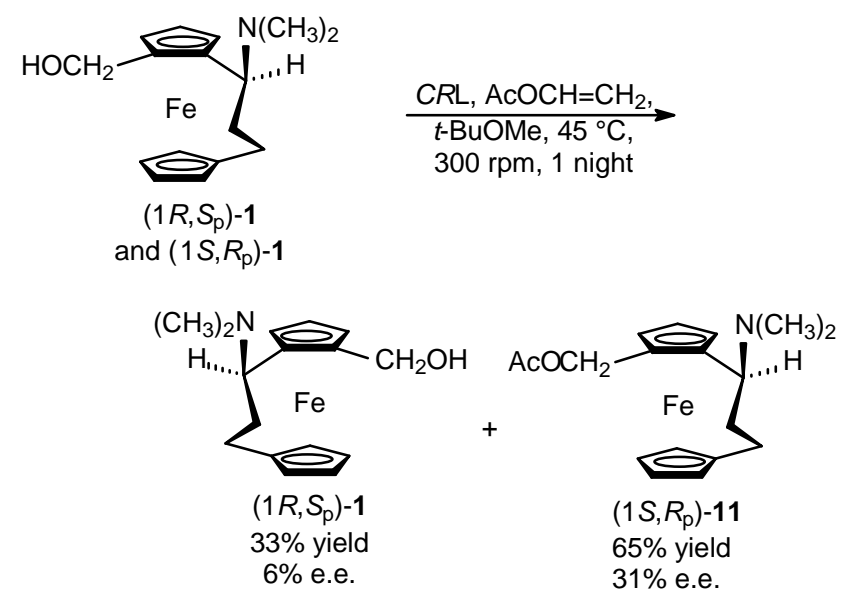

Figure 7: Enzymatic resolution of 1

A second lipase-promoted kinetic resolution was realized on the enantiomerically enriched ester $\mathbf{1 1}$ with $C R L$, in $t$ butylmethyl ether in the presence of butanol (Figure 8). ${ }^{16}$

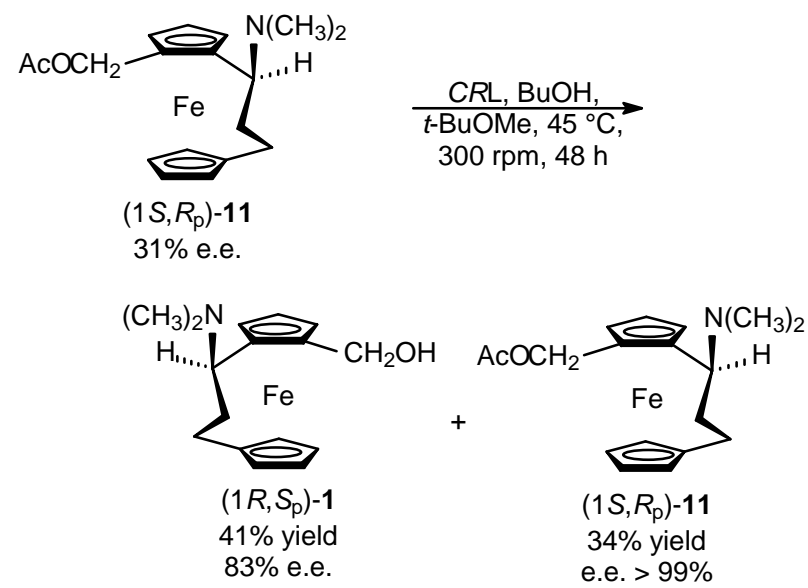

Figure 8: Enzymatic resolution of $\mathbf{1 1}$ 
In this manner, the optically pure ester $\left(1 S, R_{\mathrm{p}}\right)-\mathbf{1 1}$ was obtained $\left([\alpha]_{\mathrm{D}}^{20}=-73.4\left(3.4 ; \mathrm{CHCl}_{3}\right)\right)$. This compound could then be converted into the optically pure alcohol $\left(1 S, R_{\mathrm{p}}\right) \mathbf{- 1}$ by a simple and quantitative saponification by $\mathrm{NaOH}(\mathrm{Figure} 9)$. This alcohol is dextrogyre $\left([\alpha]_{\mathrm{D}}^{20}=+145.3\left(0.6 ; \mathrm{CHCl}_{3}\right)\right)$.

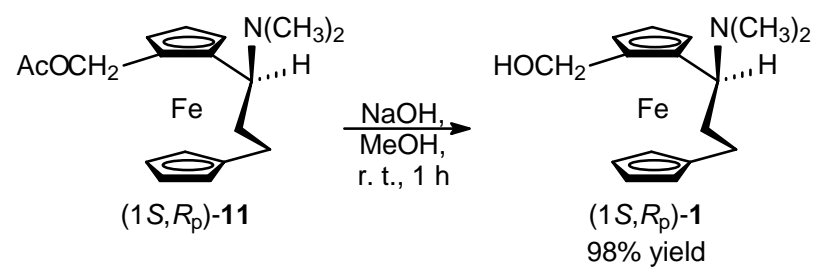

Figure 9: Saponification of $\left(1 S, R_{\mathrm{p}}\right)-\mathbf{1 1}$

Regarding the poor enantiomeric excess of ester $\mathbf{1 1}$ before resolution, we sought to realize the same reaction directly on racemic ester. Effectively, the enzymatic resolution yielded $43 \%$ of alcohol $\left(1 R, S_{\mathrm{p}}\right)-\mathbf{1}\left(72 \%\right.$ ee) and $35 \%$ of ester $\left(1 S, R_{\mathrm{p}}\right)-\mathbf{1 1}$ $($ ee $>99 \%)$. This excellent result could allow to avoid the first step of enzymatic resolution of alcohol 1, which could simply be replaced by a classical acylation.

The absolute configurations of $\mathbf{1}$ and $\mathbf{1 1}$ were determined according to Sok et al. ${ }^{17}$ Indeed, they proved that the dextrogyre alcohol results from the levogyre amine, which has got the $S$ configuration. Because of the presence of the nitrogen, the lithiation and the functionalization of only one ortho position involve the production of the 1,2 difunctionalized ferrocene having the $R_{\mathrm{p}}$ configuration (cf Figure 6).

The two other aminoalcohols were synthesized from optically pure $\mathbf{1}$.

Oxidation of $\left(1 S, R_{\mathrm{p}}\right)-\mathbf{1}$ by $\mathrm{MnO}_{2}$ yielded enantiopure aminoaldehyde $\left(1 S, R_{\mathrm{p}}\right)-\mathbf{1 0}\left([\alpha]_{\mathrm{D}}^{20}=-558,8\left(0.1 ; \mathrm{CHCl}_{3}\right)\right)$. This compound was then treated with two different alkyllithium $\left(\mathrm{R}=\mathrm{CH}_{3}\right.$ or $\mathrm{Ph}$ ) to produce the two secondary alcohols (Figure 10).
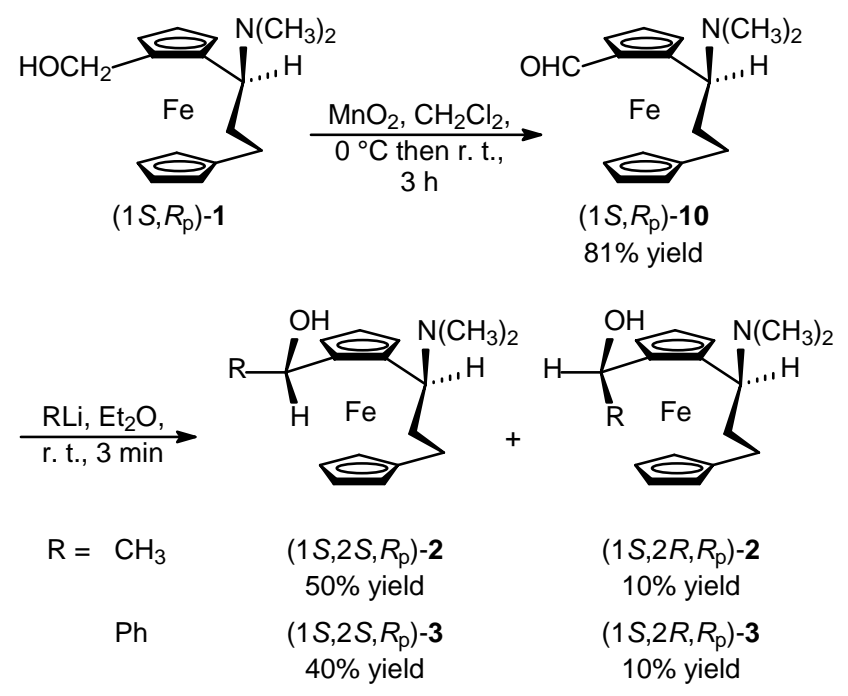

Figure 10: Synthesis of $\left(1 S, 2 S, R_{\mathrm{p}}\right)-2$ and $\left(1 S, 2 S, R_{\mathrm{p}}\right)-\mathbf{3}$

The alkylation step with RLi, produced the diastereomeric mixtures of aminoalcohols $\left(1 S, 2 S, R_{\mathrm{p}}\right)-2 /\left(1 S, 2 R, R_{\mathrm{p}}\right)-2$ and $\left(1 S, 2 S, R_{\mathrm{p}}\right)-3 /\left(1 S, 2 R, R_{\mathrm{p}}\right)-3$, which were separated by silica gel chromatography. Configurations of the new chiral centers were determined by ${ }^{1} \mathrm{H}$ NMR and according to Battelle's work on similar compounds. ${ }^{18}$ Indeed, $\left(1 S, 2 S, R_{\mathrm{p}}\right)-2$ exhibited a deshielded quadruplet at $5.07 \mathrm{ppm}$ attributed to the hydrogen near the alcohol function $\mathrm{Fc}-\mathrm{CH}(\mathrm{OH})$, whereas the corresponding quadruplet was located at $4.60 \mathrm{ppm}$ for $\left(1 S, 2 R, R_{\mathrm{p}}\right)-2$. The proximity of this proton and iron can explain the deshielding observed. $\left(1 S, 2 S, R_{\mathrm{p}}\right)-2$ is dextrogyre $\left([\alpha]_{\mathrm{D}}^{20}=+94,2\left(1.1 ; \mathrm{CHCl}_{3}\right)\right)$.

The same reasoning was applied to $\left(1 S, 2 S, R_{\mathrm{p}}\right)-\mathbf{3}$ and $\left(1 S, 2 R, R_{\mathrm{p}}\right)-3$ : the hydrogen near the alcohol function of $\left(1 S, 2 S, R_{\mathrm{p}}\right)-\mathbf{3}$ appeared in the form of a deshielded singlet at $6.04 \mathrm{ppm},\left(v S .5 .68 \mathrm{ppm}\right.$ for $\left.\left(1 S, 2 R, R_{\mathrm{p}}\right)-3\right)$. The diastereoselectivity could be explained during the alkylation by the chelating of the nitrogen and oxygen atoms with lithium, which involved an attack preferentially on one side of the aldehyde function. $\left(1 S, 2 S, R_{\mathrm{p}}\right)-3$ is levogyre $\left([\alpha]_{\mathrm{D}}^{20}=-71,2\left(0.6 ; \mathrm{CHCl}_{3}\right)\right)$. 


\section{Enantioselective addition of diethylzinc to benzaldehyde using 1, 2 and 3}

The three new optically pure ferrocenyl aminoalcohols were used as catalysts in the ethylation of benzaldehyde by diethylzinc (Figure 11).

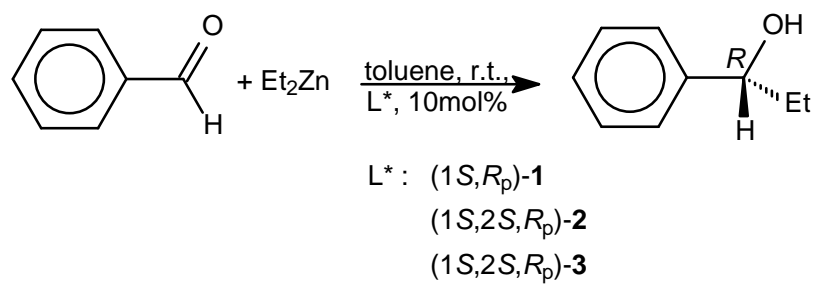

Figure 11: Catalytic ethylation of benzaldehyde by $\mathrm{Et}_{2} \mathrm{Zn}$.

The same procedure was applied for all the three catalytic reactions. The ligand was dissolved in dry toluene. Then, benzaldehyde and diethylzinc were added. The reaction was followed by GLC and was stopped after complete conversion of the aldehyde. The results are collected in Table 1.

Table 1. Catalytic ethylation of benzaldehyde by $\mathrm{Et}_{2} \mathrm{Zn}$

\begin{tabular}{|c|c|c|c|c|}
\hline \multirow[t]{2}{*}{ Entry } & \multirow[t]{2}{*}{ Ligand } & \multirow{2}{*}{$\begin{array}{c}\text { Time } \\
\text { Reaction } \\
\text { (h) }\end{array}$} & \multicolumn{2}{|c|}{ 1-Phenylpropanol } \\
\hline & & & Yield $(\%)^{\mathrm{a}}$ & $\begin{array}{c}\text { e.e. }(\%)^{\mathrm{b}} \\
\text { (configuration) }\end{array}$ \\
\hline 1 & $\left(1 S, R_{\mathrm{p}}\right)-\mathbf{1}$ & 48 & 96 & $58(1 R)$ \\
\hline 2 & $\left(1 S, 2 S, R_{\mathrm{p}}\right)-2$ & 24 & 96 & $80(1 R)$ \\
\hline 3 & $\left(1 S, 2 S, R_{\mathrm{p}}\right)-\mathbf{3}$ & 48 & 94 & $57(1 R)$ \\
\hline
\end{tabular}

${ }^{\mathrm{a}}$ Determined by ${ }^{1} \mathrm{H}$ NMR. No more benzaldehyde was observed.

${ }^{b}$ Determined by GLC analysis on FS-Cyclodex $\beta-\mathrm{I} / \mathrm{P}(30 \mathrm{~m} \times 0.24 \mathrm{~mm})$.

The ferrocenyl aminoalcohols presented good catalytic properties as each reaction occurred with good yield ( $>94 \%$ ). The enantiomeric excesses were moderate to good (between 57 and 80\%). The three ligands directed the ethylation towards the same (1R)-1-phenylpropanol enantiomer. ${ }^{19}$

The probable stereochemical course of the reaction is postulated Figures 12 and 13 based on a study of zinc complexes using molecular models and according to that proposed by Watanabe ${ }^{20}$ and Uemura $^{21}$ for 1,4-aminoalcohols.

A complexation between zinc and the aminoalcohol occurred and produced a seven membered ring (Figure 12). Then benzaldehyde and a second molecule of diethylzinc associated to form a six membered ring adjacent to the previous one forming thus the transition state (Figure 13). Usually in this transition state, the two cycles are in a chair-chair like conformation for steric reasons. However in our case, molecular models suggest that the adopted conformation could only be boat-chair: actually, the presence of the bridge between the two cyclopentadienyl rings causes an important rigidity avoiding the possibility for the complexe to adopt the chair-chair conformation.

Two transition states A and $\mathbf{B}$ could be considered. However, phenyl group in $\mathbf{B}$ lies in an axial position, close to the two methyl groups of the nitrogen atom. Thus, the most favored transition state seems to be $\mathbf{A}$ in which the phenyl group is in equatorial position without any steric repulsion. The ethylation occurs on $R e$ face of benzaldehyde, leading to the formation of (1R)-phenylpropanol (Figure 13). This is in accordance to the experimental results.

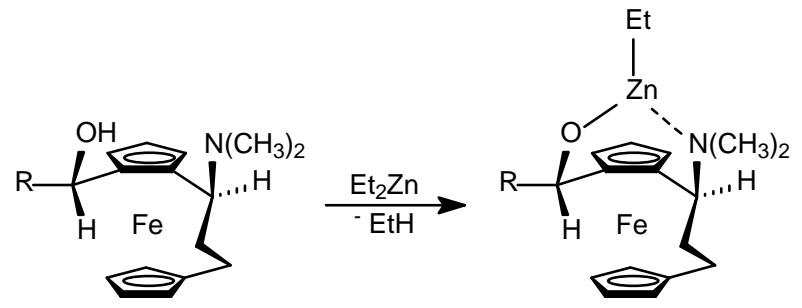

Figure 12: Complexation between diethylzinc and aminoalcohol. 

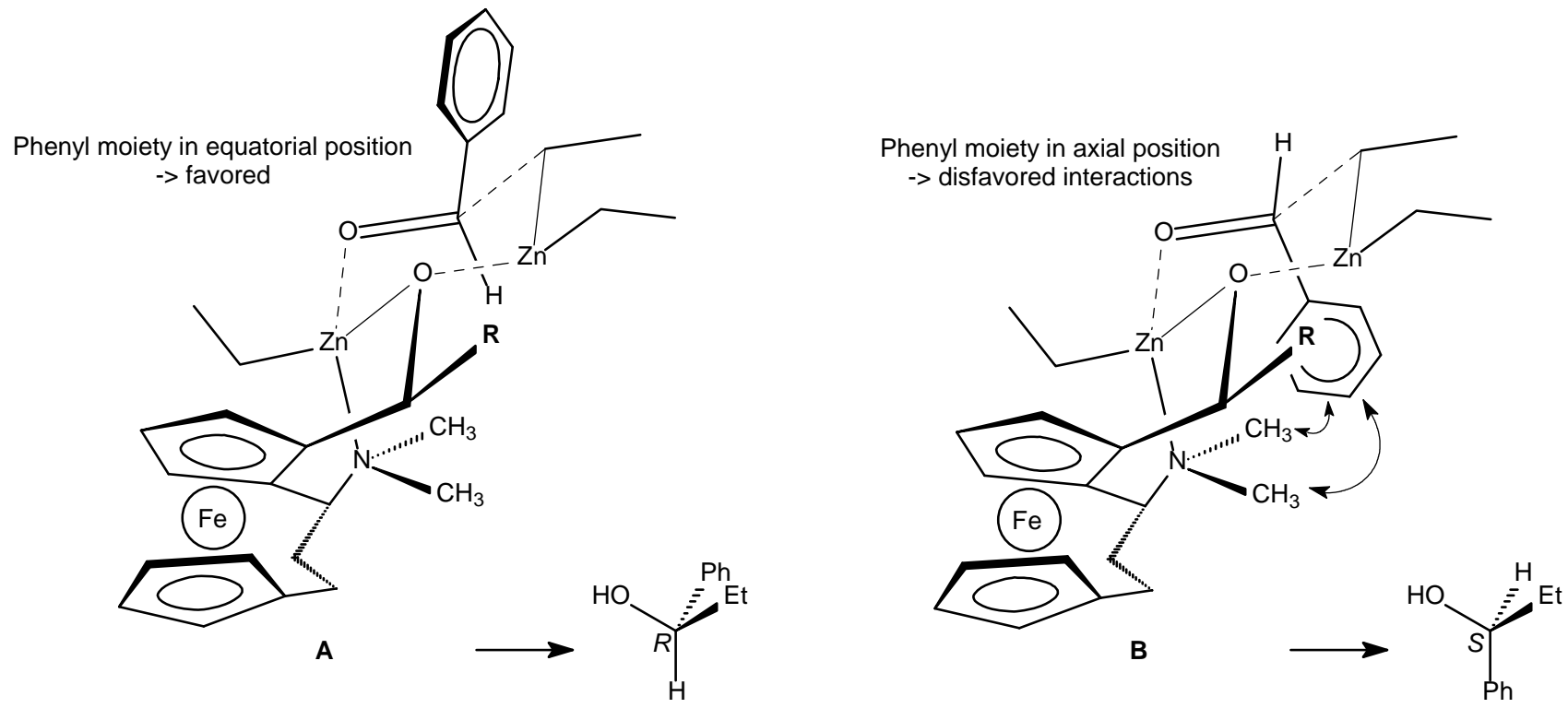

Figure 13: Proposed stereochemical course according to Uemura and Watanabe's models.

Aminoalcohol $\left(1 S, 2 S, R_{\mathrm{p}}\right)-2$ bearing the methyl group led to the best result, i.e. $96 \%$ yield and $80 \%$ e.e. (entry 2 ). Surprisingly, compound $\left(1 S, 2 S, R_{\mathrm{p}}\right)-3$ with the most hindered alcohol function (phenyl group) was not the best catalyst (57\% e.e., entry 3). In fact in the case of acyclic ferrocenyl 1,4-aminoalcohol series, it's well known that the steric hindrance of the hydroxyl group enhances the enantiomeric excesses. In our series, the cyclic chain in addition to the presence of the bulky phenyl substituent involves a loss of degree of liberty in the structure, preventing the formation of the ideal conformation to allow the best catalysis.

\section{Conclusion}

We prepared a series of enantiopure [3]ferrocenophane-based aminoalcohols $\left(1 S, R_{\mathrm{p}}\right)-\mathbf{1},\left(1 S, 2 S, R_{\mathrm{p}}\right)-\mathbf{2}$ and $\left(1 S, 2 S, R_{\mathrm{p}}\right)-\mathbf{3}$. The total optical purity was reached via an enzymatic resolution of racemic 1 . These compounds were used as ligands in the reaction of diethylzinc with benzaldehyde. $\left(1 S, 2 S, R_{\mathrm{p}}\right)-2$ proved to induce interesting properties. All the ligands directed the catalytic process towards the formation of the same $(1 R)-1$-phenylpropanol.

\section{Experimental}

\subsection{General}

The reactions were performed in glassware under an atmosphere of nitrogen. Catalytic reactions were performed under nitrogen by standard Schlenk techniques. Diethyl ether and toluene were freshly distilled over sodium prior to use. Alkyllithium reagents were purchased from Aldrich. Candida Rugosa lipases were purchased at Sigma. Column chromatographies were performed on $\mathrm{SiO}_{2}$ (Merck, 70-230 mesh, Kieselgel 60). Melting points were determined on a Kopfler apparatus. Optical rotations were measured at ambient temperature on a Perkin-Elmer 241 digital polarimeter. IR spectra were measured on a Perkin-Elmer Paragon 500 spectrometer using KBr pellets. NMR spectra were acquired at room temperature on a Bruker AC 300 spectrometer. ${ }^{1} \mathrm{H}$ NMR analyses were obtained at $300 \mathrm{MHz}$ (s: singlet, d: doublet, t: triplet, dd: double doublet, m: multiplet); ${ }^{13} \mathrm{C}$ NMR analyses were obtained at $75.4 \mathrm{MHz} .{ }^{1} \mathrm{H}$ chemical shifts are quoted relative to TMS, and ${ }^{13} \mathrm{C}$ shifts relative to solvent signals. Carbon signals were assigned by distortionless enhancement by polarization transfer (DEPT) experiments.. Mass spectra (MALDI TOF) were obtained with a Applied Biosystem Voyager DE STR mass spectrometer. Mass spectra (CI) and HRMS were performed on a Jeol JMS-700m Station mass spectrometer. Chiral GLC analyses were run on a FS CYCLODEX $\beta$-I/P (30m x 0.24) column.

\subsection{Preparation of compounds}

5.2.1. 1,1'-[1-( $N$-methylimino)propanediyl]ferrocene ((Z)-8 and (E)-8). To a solution of 1,1'-(1-oxopropanediyl)ferrocene $(5)^{13}(3.6 \mathrm{~g}, 15 \mathrm{mmol})$ in dry diethyl ether $(75 \mathrm{~mL})$ containing $10 \mathrm{~g}$ of molecular sieves $4 \AA$ were added $24 \mathrm{~mL}(47 \mathrm{mmol})$ of methylamine. The solution was stirred during $20 \mathrm{~h}$ at room temperature. The solution was filtered over celite and the solvent 
was removed under reduced pressure. $3.45 \mathrm{~g}$ of an 81/19 mixture of two diastereomers $(Z)-8$ and $(E)-8$ were obtained as orange crystals, m.p. $79^{\circ} \mathrm{C}$;

(Z)-8: ${ }^{1} \mathrm{H}$ NMR $\delta 4.32\left(4 \mathrm{H}, \mathrm{m}, \mathrm{H}\right.$ ortho Cp et Cp'), $4.20\left(2 \mathrm{H}, \mathrm{m}, \mathrm{H}\right.$ meta Cp), $4.02\left(2 \mathrm{H}, \mathrm{m}, \mathrm{H}\right.$ meta $\left.\mathrm{Cp}^{\prime}\right), 3.21\left(3 \mathrm{H}, \mathrm{s}, \mathrm{NCH}_{3}\right)$, $2.86\left(2 \mathrm{H}, \mathrm{m}, \mathrm{CH}_{2} \mathrm{C}=\mathrm{N}\right), 2.49\left(2 \mathrm{H}, \mathrm{m}, \mathrm{CH}_{2} \mathrm{Cp}\right.$ ) $){ }^{13} \mathrm{C}$ NMR $\delta 171.8(\mathrm{C}=\mathrm{N}), 87.2$ (CIV Cp), 73.7 (CIV Cp), $70.5-68.5$ (CIII $2 \mathrm{Cp}), 46.9\left(\mathrm{CH}_{2} \mathrm{C}=\mathrm{N}\right), 41.6\left(\mathrm{NCH}_{3}\right), 27.7\left(\mathrm{CH}_{2} \mathrm{Cp}^{\prime}\right)$;

(E)-8: ${ }^{1} \mathrm{H}$ NMR $\delta$ 4.50-4.34 (4H, m, H ortho Cp et Cp'), 4.18 (2H, m, H meta Cp), 4.00 (2H, m, H meta Cp'), $3.26(3 \mathrm{H}, \mathrm{s}$, $\left.\mathrm{NCH}_{3}\right), 2.85\left(2 \mathrm{H}, \mathrm{m}, \mathrm{CH}_{2} \mathrm{C}=\mathrm{N}\right), 2.48\left(2 \mathrm{H}, \mathrm{m}, \mathrm{CH}_{2} \mathrm{Cp}{ }^{\prime}\right) ;{ }^{13} \mathrm{C}$ NMR $\delta 173.1(\mathrm{C}=\mathrm{N}), 87.5(\mathrm{CIV} \mathrm{Cp}), 72.8(\mathrm{CIV} \mathrm{Cp}), 70.5-68.5$ (CIII 2Cp), $45.2\left(\mathrm{CH}_{2} \mathrm{C}=\mathrm{N}\right), 39.4\left(\mathrm{NCH}_{3}\right), 28\left(\mathrm{CH}_{2} \mathrm{Cp}\right)$; MS m/e (MALDI TOF, matrix: thap) $292[(\mathrm{M}+\mathrm{K})]^{+}, 276[(\mathrm{M}+\mathrm{Na})]^{+}$, $258,254[\mathrm{MH}]^{+}, 253[\mathrm{M}]^{+}, 247$.

5.2.2. ( \pm )-1,1'-[1-( $N$-methylamino)propanediyl]ferrocene (9). To a solution of imine (8) (3.3 g, $13.2 \mathrm{mmol})$ in dichloromethane $(80 \mathrm{~mL})$ and $145 \mathrm{~mL}$ of ethylene glycol were added $523 \mathrm{mg}(13.8 \mathrm{mmol})$ of $\mathrm{NaBH}_{4}$. The solution was stirred at ambient temperature during 24h. Water was then added. After $15 \mathrm{~min}$, the solvent was removed under reduced pressure. The product was extracted with several portions of diethyl ether, the extracts were combined, washed with water, then $\mathrm{HCl} 6 \mathrm{~N}$. To the aqueous layer was added $\mathrm{K}_{2} \mathrm{CO}_{3}$ until a precipitate appears. An extraction with diethyl ether was realized followed by a wash with twice brine. Organic layer was dried over $\mathrm{Na}_{2} \mathrm{SO}_{4}$. The solvent was removed under reduced pressure and purification through column chromatography (45\% diethyl ether $45 \%$ petroleum ether and $10 \%$ triethylamine) yielded $84 \%$ (2.8 g) of 9 as orange crystals, m.p. $50^{\circ} \mathrm{C}$; ${ }^{1} \mathrm{H}$ NMR $\delta 4.23-4.06(8 \mathrm{H}, \mathrm{m}, 2 \mathrm{Cp}), 3.05(1 \mathrm{H}, \mathrm{dd}, \mathrm{J}=7.3 \mathrm{~J}=5.6, \mathrm{CH}-$ $\mathrm{N}), 2.36\left(3 \mathrm{H}, \mathrm{s}, \mathrm{NCH}_{3}\right), 2.35\left(1 \mathrm{H}, \mathrm{m}, \mathrm{CH}_{2} \mathrm{Cp}\right), 2.13\left(2 \mathrm{H}, \mathrm{m}, \mathrm{CH}_{2} \mathrm{C}-\mathrm{N}\right), 1.94\left(1 \mathrm{H}, \mathrm{m}, \mathrm{CH}_{2} \mathrm{Cp}\right) ;{ }^{13} \mathrm{C}$ NMR $\delta 87.8(\mathrm{CIV} \mathrm{Cp}), 86.4$ (CIV Cp), 71,1-66.7 (CIII 2Cp), $58.5(\mathrm{CH}-\mathrm{N}), 42.4\left(\mathrm{CH}_{2} \mathrm{C}-\mathrm{N}\right), 35.2\left(\mathrm{NCH}_{3}\right), 23.9\left(\mathrm{CH}_{2} \mathrm{Cp}\right)$; MS m/e (MALDI TOF, matrix: thap) $294[(\mathrm{M}+\mathrm{K})]^{+}, 278[(\mathrm{M}+\mathrm{Na})]^{+}, 256[\mathrm{MH}]^{+}, 255[\mathrm{M}]^{+}, 191,169$.

5.2.3. ( \pm )-1,1'-[1-( $N, N$-dimethylamino)propanediyl]ferrocene (4). To a solution of methylamine $(9)(3 \mathrm{~g}, 11.8 \mathrm{mmol})$ in methanol $(100 \mathrm{~mL})$ were added $95 \mathrm{~mL}$ of formaldehyde $37 \%$ wt. (solution in water). The solution was stirred at $0^{\circ} \mathrm{C}$ during $10 \mathrm{~min}$, then $8.55 \mathrm{~g}$ of $\mathrm{NaBH}_{4}$ were added very carefully portion wise. The mixture was heated to reflux during $48 \mathrm{~h}$. After cooling to ambient temperature, methanol was removed under reduced pressure. The product was extracted with several portions of diethyl ether, the extracts were combined and washed twice with brine. Organic layer was dried over $\mathrm{Na}_{2} \mathrm{SO}_{4}$. The solvent was removed under reduced pressure and purification through column chromatography $(45 \%$ diethyl ether $45 \%$ petroleum ether and $10 \%$ triethylamine) yielded $82 \%(2.6 \mathrm{~g})$ of 4 as orange crystals, m.p. $90{ }^{\circ} \mathrm{C} ;{ }^{1} \mathrm{H} \mathrm{NMR} \delta 4.17-3.89(8 \mathrm{H}$, m, $2 \mathrm{Cp}), 2.82(1 \mathrm{H}, \mathrm{dd}, \mathrm{J}=10.0 \mathrm{~J}=3.0, \mathrm{CH}-\mathrm{N}), 2.47\left(1 \mathrm{H}, \mathrm{m}, \mathrm{CH}_{2} \mathrm{Cp}\right), 2.19\left(6 \mathrm{H}, \mathrm{s}, \mathrm{N}\left(\mathrm{CH}_{3}\right)_{2}\right), 2.16\left(1 \mathrm{H}, \mathrm{m}, \mathrm{CH}{ }_{2} \mathrm{C}-\mathrm{N}\right), 2.13(1 \mathrm{H}, \mathrm{m}$, $\mathrm{CH}_{2} \mathrm{C}-\mathrm{N}$ ), $1.93\left(1 \mathrm{H}, \mathrm{m}, \mathrm{CH}_{2} \mathrm{Cp}\right.$ ); ${ }^{13} \mathrm{C}$ NMR $\delta 87.7$ (CIV Cp), 80.5 (CIV Cp), 71,8-67.0 (CIII 2Cp), 65.4 (CH-N), 42.9 $\left(\mathrm{N}\left(\mathrm{CH}_{3}\right)_{2}\right), 39.6\left(\mathrm{CH}_{2} \mathrm{C}-\mathrm{N}\right), 25.9\left(\mathrm{CH}_{2} \mathrm{Cp}\right)$; MS m/e (MALDI TOF, matrix: thap) $308[(\mathrm{M}+\mathrm{K})]^{+}, 292[(\mathrm{M}+\mathrm{Na})]^{+}, 270[\mathrm{MH}]^{+}$, $269[\mathrm{M}]^{+}, 225\left[\mathrm{M}-\mathrm{NMe}_{2}\right]^{+}, 207,191,169$.

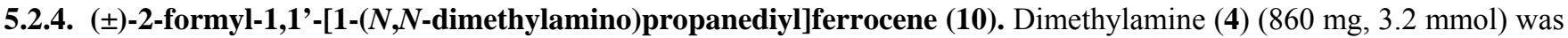
placed at room temperature under an inert atmosphere in a round-bottomed flask and then dissolved in dry diethyl ether (35 $\mathrm{mL})$. After 5 minutes stirring, $t$-BuLi $(2.7 \mathrm{~mL}, 4 \mathrm{mmol}, 1.5 \mathrm{M}$ in pentane) was added slowly and the solution was stirred for another $1 \mathrm{~h}$. Then, $0.5 \mathrm{~mL}$ of DMF $(6.4 \mathrm{mmol})$ was added. The solution was stirred for 15 minutes, quenched with watersaturated diethyl ether $(20 \mathrm{~mL})$ and with brine $(20 \mathrm{~mL})$. The organic compounds were extracted with diethyl ether $(2 \times 20$ $\mathrm{mL})$, the extracts were combined, washed with brine $(2 \times 60 \mathrm{~mL})$ and dried over $\mathrm{Na}_{2} \mathrm{SO}_{4}$. The solvent was removed under reduced pressure and purification through column chromatography (45\% diethyl ether 45\% petroleum ether and $10 \%$ triethylamine) yielded $71 \%(675 \mathrm{mg})$ of 10 as a red oil; IR $\left(\mathrm{cm}^{-1}\right)$ 3087, 2950, 2860, 2818, 2770, 1672, 1469, 1438, 1349, $1253,1037,1015,810 ;{ }^{1} \mathrm{H}$ NMR $\delta 10.38(1 \mathrm{H}, \mathrm{s},-\mathrm{CHO}), 4.82(1 \mathrm{H}, \mathrm{m}, \mathrm{Cp}), 4.46(1 \mathrm{H}, \mathrm{m}, \mathrm{Cp}), 4.41(1 \mathrm{H}, \mathrm{m}, \mathrm{Cp}), 4.26(2 \mathrm{H}, \mathrm{m}$, Cp), $4.01(1 \mathrm{H}, \mathrm{m}, \mathrm{Cp}), 3.96(1 \mathrm{H}, \mathrm{m}, \mathrm{Cp}), 2.77(1 \mathrm{H}, \mathrm{dd}, \mathrm{J}=10.8 \mathrm{~J}=2.8, \mathrm{CH}-\mathrm{N}), 2.51\left(1 \mathrm{H}, \mathrm{m}, \mathrm{CH}_{2} \mathrm{C}-\mathrm{N}\right), 2.51\left(1 \mathrm{H}, \mathrm{m}, \mathrm{CH}{ }_{2} \mathrm{Cp}\right)$, $2.36\left(1 \mathrm{H}, \mathrm{m}, \mathrm{CH}_{2} \mathrm{C}-\mathrm{N}\right), 2.27\left(6 \mathrm{H}, \mathrm{s},-\mathrm{N}\left(\mathrm{CH}_{3}\right)_{2}\right), 1.95\left(1 \mathrm{H}, \mathrm{m}, \mathrm{CH}_{2} \mathrm{Cp}\right) ;{ }^{13} \mathrm{C}$ NMR $\delta 196.2$ (CHO), 89.5 (CIV Cp), 87.5 (CIV

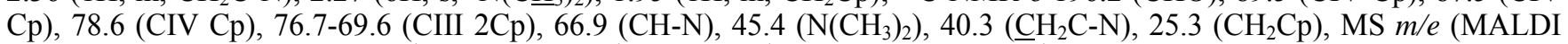
TOF, matrix: thap) $336[(\mathrm{M}+\mathrm{K})]^{+}, 320[(\mathrm{M}+\mathrm{Na})]^{+}, 298[\mathrm{MH}]^{+}, 266,253\left[\mathrm{M}-\mathrm{NMe}_{2}\right]^{+}, 225,207,191$.

5.2.5. ( \pm )-2-(hydroxymethyl)-1,1'-[1-( $N, N$-dimethylamino)propanediyl]ferrocene (1). To a solution of aldehyde 10 (3 g, $10 \mathrm{mmol})$ in methanol $(150 \mathrm{~mL})$ was added $\mathrm{NaBH}_{4}(14.8 \mathrm{~g}, 0.39 \mathrm{~mol})$. The solution was stirred until discoloration. A hydrolysis was performed by adding water. Methanol was evaporated under reduced pressure. The product was extracted with several portions of diethyl ether, the extracts were combined, washed twice with brine and dried over $\mathrm{Na}_{2} \mathrm{SO}_{4}$. The solvent was removed under reduced pressure and purification through column chromatography (45\% diethyl ether $45 \%$ petroleum ether and 10\% triethylamine) yielded $91 \%(2.72 \mathrm{~g})$ of 1 as a dark orange oil; IR $\left(\mathrm{cm}^{-1}\right) 3381,3205,3078,2953$, 2858, 2816, 2783, 1470, 1429, 1350, 1205, 1016, 893, 839, 802; ${ }^{1} \mathrm{H}$ NMR $\delta 4.85\left(1 \mathrm{H}, \mathrm{d}, J=12.7, \mathrm{CH}_{2} \mathrm{O}\right), 4.14(1 \mathrm{H}, \mathrm{m}, \mathrm{Cp})$, $4.10\left(1 \mathrm{H}, \mathrm{d}, J=12.7, \mathrm{CH}_{2} \mathrm{O}\right), 4.05(2 \mathrm{H}, \mathrm{m}, \mathrm{Cp}), 4.00(1 \mathrm{H}, \mathrm{m}, \mathrm{Cp}), 3.94(2 \mathrm{H}, \mathrm{m}, \mathrm{Cp}), 3.70(1 \mathrm{H}, \mathrm{m}, \mathrm{Cp}), 2.60(1 \mathrm{H}, \mathrm{m}, \mathrm{CH} 2 \mathrm{Cp})$, $2.51\left(1 \mathrm{H}, \mathrm{m}, \mathrm{CH}_{2} \mathrm{Cp}\right), 2.47(1 \mathrm{H}, \mathrm{m}, \mathrm{CH}-\mathrm{N}), 2.32\left(6 \mathrm{H}, \mathrm{s},-\mathrm{N}\left(\mathrm{CH}_{3}\right)_{2}\right), 2.22\left(1 \mathrm{H}, \mathrm{m}, \mathrm{CH}_{2} \mathrm{C}-\mathrm{N}\right), 1.95\left(1 \mathrm{H}, \mathrm{m}_{,} \mathrm{CH}_{2} \mathrm{C}-\mathrm{N}\right) ;{ }^{13} \mathrm{C} \mathrm{NMR}$ $\delta 87.3$ (CIV Cp), 86.3 (CIV Cp), 85.5 (CIV Cp), 71.5-66.1 (CIII 2Cp), 61.1 ( $\left.\mathrm{CH}_{2} \mathrm{O}\right), 66.2(\mathrm{CH}-\mathrm{N}), 44.9\left(\mathrm{~N}\left(\mathrm{CH}_{3}\right)_{2}\right), 37.5$ $\left(\mathrm{CH}_{2} \mathrm{C}-\mathrm{N}\right), 25.1\left(\mathrm{CH}_{2} \mathrm{Cp}\right), \mathrm{MS}$ m/e (MALDI TOF, matrix: thap) $336[(\mathrm{M}+\mathrm{K})]^{+}, 320[(\mathrm{M}+\mathrm{Na})]^{+}, 298[\mathrm{MH}]^{+}, 266,253[\mathrm{M}-$ $\left.\mathrm{NMe}_{2}\right]^{+}, 225,207,191$; HRMS (CI) Calcd for $\mathrm{C}_{16} \mathrm{H}_{21}$ FeNO: 299.0973; Found: 299.0980. 
5.2.6. Procedure for enzymatic resolution of 2 -(hydroxymethyl)-1,1'-[1-( $N, N$-dimethylamino)propanediyl]ferrocene (1). To a solution of alcohol 1 (1.43 g, $4.8 \mathrm{mmol})$ and $730 \mathrm{mg}$ of Candida Rugosa lipases in tert-butylmethyl ether (30 mL) were added $20 \mathrm{~mL}(21.8 \mathrm{mmol})$ of vinyl acetate. The solution was stirred $(300 \mathrm{rpm})$ at $45^{\circ} \mathrm{C}$ during $14 \mathrm{~h}$. The reaction mixture was then filtered over celite. After evaporation of the solvent under reduced pressure, the residue was purified through column chromatography (45\% diethyl ether $45 \%$ petroleum ether and $10 \%$ triethylamine to $90 \%$ diethyl ether and $10 \%$ triethylamine) yielded 33\% (500 mg) of $\left(1 S, R_{\mathrm{p}}\right)-11($ e.e. $=31 \%)$ and $65 \%(963 \mathrm{mg})$ of $\left(1 R, S_{\mathrm{p}}\right)-1(\mathrm{e} . \mathrm{e} .=6 \%)$.

5.2.7. (1S, $\left.R_{\mathrm{p}}\right)$-2-(acetoxymethyl)-1,1'-[1-( $N, N$-dimethylamino)propanediyl]ferrocene (11). To a solution of racemic ester $\left(1 S, R_{\mathrm{p}}\right)-11(500 \mathrm{mg}, 1.5 \mathrm{mmol})$ and $20 \mathrm{~g}$ of Candida Rugosa lipases in tert-butylmethyl ether $(50 \mathrm{~mL})$ were added $4 \mathrm{~mL}$ of butanol. The solution was stirred $(300 \mathrm{rpm})$ at $45^{\circ} \mathrm{C}$ during $48 \mathrm{~h}$. The reaction mixture was then filtered over celite. After evaporation of the solvent under reduced pressure, the residue was purified through column chromatography (45\% diethyl ether $45 \%$ petroleum ether and $10 \%$ triethylamine to $90 \%$ diethyl ether and $10 \%$ triethylamine) yielded $43 \%$ (192 mg) of $\left(1 R, S_{\mathrm{p}}\right)-\mathbf{1}(\mathrm{e} . \mathrm{e} .=72 \%)$ and $35 \%(171 \mathrm{mg})$ of $\left(1 S, R_{\mathrm{p}}\right)-\mathbf{1 1}(\mathrm{e} . \mathrm{e}>99 \%) .\left(1 S, R_{\mathrm{p}}\right)-\mathbf{1 1}$ : orange oil; $[\alpha]_{\mathrm{D}}^{20}=-73.4\left(3.4 ; \mathrm{CHCl}_{3}\right) ; \mathrm{IR}$ $\left(\mathrm{cm}^{-1}\right) 3087,2951,2862,2815,2765,1737,1468,1447,1372,1357,1239,1031,1021,891,841,804 ;{ }^{1} \mathrm{H} \mathrm{NMR} \delta 5.03(2 \mathrm{H}$, s, $\left.\mathrm{CH}_{2} \mathrm{O}\right), 4.19(1 \mathrm{H}, \mathrm{m}, \mathrm{Cp}), 4.11-4.06(3 \mathrm{H}, \mathrm{m}, \mathrm{Cp}), 3.98-3.96(3 \mathrm{H}, \mathrm{m}, \mathrm{Cp}), 2.53(1 \mathrm{H}, \mathrm{m}, \mathrm{CH}-\mathrm{N}), 2.43\left(2 \mathrm{H}, \mathrm{m}, \mathrm{CH}_{2} \mathrm{Cp}\right), 2.23$ $\left(6 \mathrm{H}, \mathrm{s},-\mathrm{N}\left(\mathrm{CH}_{3}\right)_{2}\right), 2.15\left(1 \mathrm{H}, \mathrm{m}, \mathrm{CH}_{2} \mathrm{C}-\mathrm{N}\right), 2.04\left(3 \mathrm{H}, \mathrm{m}, \mathrm{CH}_{3} \mathrm{CO}\right), 1.90\left(1 \mathrm{H}, \mathrm{m}, \mathrm{CH}_{2} \mathrm{C}-\mathrm{N}\right) ;{ }^{13} \mathrm{C} \mathrm{NMR} \delta 171.0(\mathrm{C}=\mathrm{O}), 88.2$ (CIV Cp), 83.7 (CIV Cp), 80.8 (CIV Cp), 72.3 (CIII Cp), 71.6-71.5 (2CIII Cp), 69.5 (2CIII Cp), 67.8 (CIII Cp), 67.6 (CIII

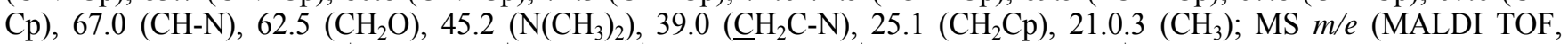
matrix: thap) $380[(\mathrm{M}+\mathrm{K})]^{+}, 342[\mathrm{MH}]^{+}, 341[\mathrm{M}]^{+}, 297\left[\mathrm{M}-\mathrm{NMe}_{2}\right]^{+}, 282\left[\mathrm{M}-\mathrm{COOCH}_{3}\right]^{+}, 257,239,207,191,169$; HRMS (CI) Calcd for $\mathrm{C}_{18} \mathrm{H}_{23} \mathrm{FeNO}_{2}$ : 341.1078; Found: 341.1082 .

5.2.8. (1S, $\left.R_{\mathrm{p}}\right)$-2-(hydroxymethyl)-1,1'-[1-( $N, N$-dimethylamino)propanediyl]ferrocene (1). To a solution of ester (1S, $\left.R_{\mathrm{p}}\right)$ $11(400 \mathrm{mg}, 1.2 \mathrm{mmol})$ in methanol $(50 \mathrm{~mL})$ was added $12 \mathrm{~mL}$ of a $1 \mathrm{~N}$ aqueous solution of $\mathrm{NaOH}(12 \mathrm{~mol})$. The solution was stirred at ambient temperature during 1 hour. Methanol was evaporated under reduced pressure. The product was extracted with several portions of diethyl ether, the extracts were combined, washed twice with brine and dried over $\mathrm{Na}_{2} \mathrm{SO}_{4}$. The solvent was removed under reduced pressure and purification through column chromatography (45\% diethyl ether $45 \%$ petroleum ether and $10 \%$ triethylamine to $90 \%$ diethyl ether and $10 \%$ triethylamine) yielded $98 \%(352 \mathrm{mg})$ of $\left(1 S, R_{\mathrm{p}}\right)-1 \mathrm{as}$ orange crystals, m.p. $94^{\circ} \mathrm{C} ;[\alpha]_{\mathrm{D}}^{20}=+145.3\left(0.6 ; \mathrm{CHCl}_{3}\right)$.

5.2.9. (1S, $\left.\boldsymbol{R}_{\mathrm{p}}\right)$-2-formyl-1,1'-[1-( $\boldsymbol{N}, \boldsymbol{N}$-dimethylamino)propanediyl]ferrocene (10). Manganese dioxide (1.3 $\left.\mathrm{mg}, 15 \mathrm{mmol}\right)$ was added to a solution of alcohol $\left(1 S, R_{\mathrm{p}}\right)-\mathbf{1}(218 \mathrm{mg}, 0.73 \mathrm{mmol})$ in dichloromethane $(30 \mathrm{~mL})$ at $0^{\circ} \mathrm{C}$. The reaction was allowed to warm to room temperature. After $3 \mathrm{~h}$, the solution was filtered over celite and the solvent evaporated under reduced pressure and purification through column chromatography (45\% diethyl ether $45 \%$ petroleum ether and $10 \%$ triethylamine to $90 \%$ diethyl ether and $10 \%$ triethylamine) yielded $81 \%(175 \mathrm{mg})$ of $\left(1 S, R_{\mathrm{p}}\right)-10$ as a dark red oil; $[\alpha]_{\mathrm{D}}^{20}=-$ $558.8\left(0.1 ; \mathrm{CHCl}_{3}\right)$.

5.2.10. (1S,2S, $\left.R_{\mathrm{p}}\right)$-2-(1-hydroxyethyl)-1,1'-[1-( $N, N$-dimethylamino)propanediyl]ferrocene (2). A solution of aldehyde $\left(1 S, R_{\mathrm{p}}\right)-10(160 \mathrm{mg}, 0.54 \mathrm{mmol})$ in dry diethyl ether $(20 \mathrm{~mL})$ was stirred at room temperature under nitrogen. After $15 \mathrm{~min}$, $0.5 \mathrm{~mL}$ of methyllithium $(1.6 \mathrm{M}, 0.81 \mathrm{mmol})$ was slowly added. After $3 \mathrm{~min}$, the solution was hydrolyzed with $20 \mathrm{~mL}$ of water-saturated diethyl ether and then with $20 \mathrm{~mL}$ of brine. The organics were extracted with several portions of diethyl ether, and the extracts were combined, washed twice with brine and dried over $\mathrm{Na} 2 \mathrm{SO} 4$. The solvent was removed under reduced pressure and purification through column chromatography (70\% diethyl ether, 20\% petroleum ether and $10 \%$ triethylamine) yielded $50 \%(84 \mathrm{mg})$ of $\left(1 S, 2 \mathrm{~S}, R_{\mathrm{p}}\right)-2$ as yellow crystals $\left(\mathrm{m} . \mathrm{p} .112^{\circ} \mathrm{C}\right)$ and $10 \%$ of $\left(1 S, 2 R, R_{\mathrm{p}}\right)-2$ as an orange oil;

$\left(1 S, 2 \mathrm{~S}, R_{\mathrm{p}}\right)-2:[\alpha]_{\mathrm{D}}^{20}=+94.2\left(1.1 ; \mathrm{CHCl}_{3}\right) ; \mathrm{IR}\left(\mathrm{cm}^{-1}\right)$ 3406, 3229, 3087, 2971, 2951, 2925, 2892, 2821, 2777, 1470, 1458, 1426, 1359, 1342, 1093, 1036, 991, 889, 876, 832, 802; ${ }^{1} \mathrm{H}$ NMR $\delta 5.07$ (1H, q J=6.0, -CHO), $4.16(1 \mathrm{H}, \mathrm{m}, \mathrm{Cp}), 4.12(1 \mathrm{H}, \mathrm{m}$, $\mathrm{Cp}), 4.05$ (1H, m, Cp), 3.97 (2H, m, Cp), $3.95(1 \mathrm{H}, \mathrm{m}, \mathrm{Cp}), 3.64(1 \mathrm{H}, \mathrm{m}, \mathrm{Cp}), 2.62\left(1 \mathrm{H}, \mathrm{m}, \mathrm{CH}_{2} \mathrm{Cp}\right), 2.51\left(1 \mathrm{H}, \mathrm{m}, \mathrm{CH} \mathrm{C}_{2} \mathrm{~N}\right)$, $2.47(1 \mathrm{H}, \mathrm{m}, \mathrm{CH}-\mathrm{N}), 2.31\left(6 \mathrm{H}, \mathrm{s},-\mathrm{N}\left(\mathrm{CH}_{3}\right)_{2}\right), 2.28\left(1 \mathrm{H}, \mathrm{m}, \mathrm{CH}_{2} \mathrm{C}-\mathrm{N}\right), 1.93\left(1 \mathrm{H}, \mathrm{m}, \mathrm{CH}_{2} \mathrm{C}-\mathrm{N}\right), 1.42\left(3 \mathrm{H}, \mathrm{d} \mathrm{J}=6.0, \mathrm{CH}_{3}\right) ;{ }^{13} \mathrm{C}$ NMR $\delta 90.5$ (CIV Cp), 87.5 (CIV Cp), 85.4 (CIV Cp), 71.9 (CIII Cp), 71.5 (CIII Cp), 71.2 (CIII Cp), 69.6 (CIII Cp), 67.9 (CIII Cp), 67.1 (CIII Cp), 66.5 (CH-N), 66.2 (CHO), 64.8 (CIII Cp), $44.9\left(\mathrm{~N}_{\left(\mathrm{CH}_{3}\right)}\right), 37.2\left(\underline{\mathrm{CH}}_{2} \mathrm{C}-\mathrm{N}\right), 25.4\left(\mathrm{CH}{ }_{2} \mathrm{Cp}\right), 20.3$ $\left(\mathrm{CH}_{3}\right)$; MS m/e (MALDI TOF, matrix: thap) $352[(\mathrm{M}+\mathrm{K})]^{+}, 336[(\mathrm{M}+\mathrm{Na})]^{+}, 314[\mathrm{MH}]^{+}, 313[\mathrm{M}]^{+}, 251,207,191,169,148$; HRMS (CI) Calcd for $\mathrm{C}_{17} \mathrm{H}_{23} \mathrm{FeNO}$ : 313.1129; Found: 313.1125.

$\left(1 S, 2 R, R_{\mathrm{p}}\right)-2:[\alpha]_{\mathrm{D}}^{20}=-9.4\left(0.4 ; \mathrm{CHCl}_{3}\right) ;{ }^{1} \mathrm{H}$ NMR $\delta 4.60(1 \mathrm{H}, \mathrm{q} J=6.3,-\mathrm{CHO}), 4.49(1 \mathrm{H}, \mathrm{m}, \mathrm{Cp}), 4.10(1 \mathrm{H}, \mathrm{m}, \mathrm{Cp}), 4.08(1 \mathrm{H}$, m, Cp), $3.98(2 \mathrm{H}, \mathrm{m}, \mathrm{Cp}), 3.95(1 \mathrm{H}, \mathrm{m}, \mathrm{Cp}), 3.89(1 \mathrm{H}, \mathrm{m}, \mathrm{Cp}), 2.56\left(1 \mathrm{H}, \mathrm{m}, \mathrm{CH}_{2} \mathrm{C}-\mathrm{N}\right), 2.50\left(1 \mathrm{H}, \mathrm{m}, \mathrm{CH}{ }_{2} \mathrm{Cp}\right), 2.48(1 \mathrm{H}, \mathrm{m}$, $\mathrm{CH}-\mathrm{N}), 2.33\left(1 \mathrm{H}, \mathrm{m}, \mathrm{CH}_{2} \mathrm{C}-\mathrm{N}\right), 2.30\left(6 \mathrm{H}, \mathrm{s},-\mathrm{N}\left(\mathrm{CH}_{3}\right)_{2}\right), 1.85\left(1 \mathrm{H}, \mathrm{m}, \mathrm{CH}_{2} \mathrm{Cp}\right), 1.44\left(3 \mathrm{H}, \mathrm{d} J=6.3, \mathrm{CH}_{3}\right) ;{ }^{13} \mathrm{C} \mathrm{NMR} \delta 94.7$ (CIV Cp), 87.4 (CIV Cp), 82.8 (CIV Cp), 71.3 (CIII Cp), 70.6 (CIII Cp), 69.4 (CIII Cp), 68.5 (CIII Cp), 68.1 (CIII Cp), 68 (CIII Cp), 66.4 (CIII Cp), $65.7(\mathrm{CH}-\mathrm{N}), 63.9(\mathrm{CHO}), 44.5\left(\mathrm{~N}\left(\mathrm{CH}_{3}\right)_{2}\right), 38.2\left(\mathrm{CH}_{2} \mathrm{C}-\mathrm{N}\right), 24.2\left(\mathrm{CH}_{2} \mathrm{Cp}\right), 23.1\left(\mathrm{CH}_{3}\right)$.

5.2.11. (1S,2S, $\left.R_{\mathrm{p}}\right)$-2-(1-hydroxy-1-phenylmethyl)-1,1'-[1-( $N, N$-dimethylamino)propanediyl]ferrocene (3). A solution of aldehyde $\left(1 S, R_{\mathrm{p}}\right)-\mathbf{1 0}(160 \mathrm{mg}, 0.54 \mathrm{mmol})$ in dry diethyl ether $(20 \mathrm{~mL})$ was stirred at room temperature under nitrogen. After 
$15 \mathrm{~min}, 0.4 \mathrm{~mL}$ of phenyllithium (2M, $0.8 \mathrm{mmol}$ ) was slowly added. After $3 \mathrm{~min}$, the solution was hydrolyzed with $20 \mathrm{~mL}$ of water-saturated diethyl ether and then with $20 \mathrm{~mL}$ of brine. The organics were extracted with several portions of diethyl ether, and the extracts were combined, washed twice with brine and dried over $\mathrm{Na} 2 \mathrm{SO} 4$. The solvent was removed under reduced pressure and purification through column chromatography (70\% diethyl ether, 20\% petroleum ether and $10 \%$ triethylamine) yielded $40 \%(81 \mathrm{mg})$ of $\left(1 S, 2 \mathrm{~S}, R_{\mathrm{p}}\right)-3$ as an orange oil and $10 \%$ of $\left(1 S, 2 R, R_{\mathrm{p}}\right)-3$ as an orange oil;

$\left(1 S, 2 \mathrm{~S}, R_{\mathrm{p}}\right)-3:[\alpha]_{\mathrm{D}}^{20}=-71.2\left(0.6 ; \mathrm{CHCl}_{3}\right) ; \mathrm{IR}\left(\mathrm{cm}^{-1}\right) 3166,3086,2951,2900,2847,2821,2776,1470,1448,1348,1324$, $1239,1201,1038,1018,893,843,806,736,699,668 ;{ }^{1} \mathrm{H}$ NMR $\delta 7.48$ (2H, d $J=7.4, \mathrm{H}$ ortho Ph), 7.34 (2H, t $J=7.4, \mathrm{H}$ meta $\mathrm{Ph}), 7.26$ (1H, t J=7.4, H para Ph), 6.04 (1H, s, -CH-O), 4.10 (1H, m, Cp), 4.05 (1H, m, Cp), 3.99 (1H, m, Cp), 3.92 (1H, m, $\mathrm{Cp}), 3.91(1 \mathrm{H}, \mathrm{m}, \mathrm{Cp}), 3.83(1 \mathrm{H}, \mathrm{m}, \mathrm{Cp}), 3.25(1 \mathrm{H}, \mathrm{m}, \mathrm{Cp}), 2.70\left(1 \mathrm{H}, \mathrm{m}, \mathrm{CH}_{2} \mathrm{Cp}\right), 2.59\left(1 \mathrm{H}, \mathrm{m}, \mathrm{CH}_{2} \mathrm{C}-\mathrm{N}\right), 2.53(1 \mathrm{H}, \mathrm{m}, \mathrm{CH}-$ $\mathrm{N}), 2.42\left(1 \mathrm{H}, \mathrm{m}, \mathrm{CH}_{2} \mathrm{C}-\mathrm{N}\right), 2.37\left(6 \mathrm{H}, \mathrm{s},-\mathrm{N}\left(\mathrm{CH}_{3}\right)_{2}\right), 1.99\left(1 \mathrm{H}, \mathrm{m}, \mathrm{CH}_{2} \mathrm{Cp}\right) ;{ }^{13} \mathrm{C} \mathrm{NMR} \delta 142.5(\mathrm{CIV}, \mathrm{Ph}), 127.8(\mathrm{CIII}$ meta, $\mathrm{Ph})$, 127.0 (CIII para, Ph), 126.7 (CIII ortho, Ph), 91.6 (CIV Cp), 87.7 (CIV Cp), 84.6 (CIV Cp), 72.7 (CIII Cp), 72.2 (CIII Cp), 71.8 (CHO), 71.2 (CIII Cp), 71.0 (CIII Cp), 70.0 (CIII Cp), 67.2 (CIII Cp), 66.5 (CH-N), 65.9 (CIII Cp), 44.8 (N(CH $\left.)_{2}\right)$, $37.5\left(\mathrm{CH}_{2} \mathrm{C}-\mathrm{N}\right), 25.5\left(\mathrm{CH}_{2} \mathrm{Cp}\right)$; MS m/e (MALDI TOF, matrix: thap) $414[(\mathrm{M}+\mathrm{K})]^{+}, 398[(\mathrm{M}+\mathrm{Na})]^{+}, 376[\mathrm{MH}]^{+}, 375[\mathrm{M}]^{+}$, $331\left[\mathrm{M}-\mathrm{NMe}_{2}\right]^{+}, 315,207,191,169$; HRMS (CI) Calcd for $\mathrm{C}_{22} \mathrm{H}_{25} \mathrm{FeNO}$ : 375.1286; Found: 375.1286.

$\left(1 S, 2 R, R_{\mathrm{p}}\right)-3:[\alpha]_{\mathrm{D}}^{20}=-95.2\left(0.2 ; \mathrm{CHCl}_{3}\right) ;{ }^{1} \mathrm{H} \mathrm{NMR} \delta 7.44(2 \mathrm{H}, \mathrm{d} J=7.7, \mathrm{H}$ ortho $\mathrm{Ph}), 7.34(2 \mathrm{H}, \mathrm{t} J=7.7, \mathrm{H} \mathrm{meta} \mathrm{Ph}), 7.27(1 \mathrm{H}$, t J=7.7, H para Ph), $6.04(1 \mathrm{H}, \mathrm{s},-\mathrm{CH}-\mathrm{O}), 4.48(1 \mathrm{H}, \mathrm{m}, \mathrm{Cp}), 4.18(1 \mathrm{H}, \mathrm{m}, \mathrm{Cp}), 4.11(1 \mathrm{H}, \mathrm{m}, \mathrm{Cp}), 4.08(1 \mathrm{H}, \mathrm{m}, \mathrm{Cp}), 3.92(1 \mathrm{H}$, m, Cp), 3.89 (1H, m, Cp), $3.82(1 \mathrm{H}, \mathrm{m}, \mathrm{Cp}), 3.43(1 \mathrm{H}, \mathrm{m}, \mathrm{CH}-\mathrm{N}), 3.29\left(1 \mathrm{H}, \mathrm{m}, \mathrm{CH}_{2} \mathrm{C}-\mathrm{N}\right), 2.77\left(6 \mathrm{H}, \mathrm{s},-\mathrm{N}\left(\mathrm{C} \underline{\mathrm{H}}_{3}\right)_{2}\right), 2.66(1 \mathrm{H}$, $\left.\mathrm{m}, \mathrm{CH}_{2} \mathrm{Cp}\right), 2.46\left(1 \mathrm{H}, \mathrm{m}, \mathrm{CH}_{2} \mathrm{C}-\mathrm{N}\right), 1.98\left(1 \mathrm{H}, \mathrm{m}, \mathrm{CH}_{2} \mathrm{Cp}\right) ;{ }^{13} \mathrm{C}$ NMR $\delta 143.3(\mathrm{CIV}, \mathrm{Ph}), 128.0(\mathrm{CIII} \mathrm{meta}, \mathrm{Ph}), 127.7(\mathrm{CIII}$ para, $\mathrm{Ph}$ ), 126.6 (CIII ortho, Ph), 93.4 (CIV Cp), 87.3 (CIV Cp), 72.7 (1CIV and 1CIII Cp), 72.5 (CIII Cp), 72.0 (CIII Cp),

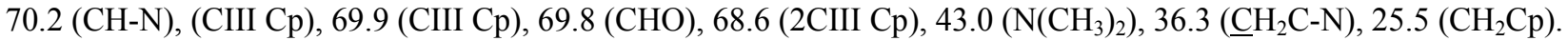

\subsubsection{General procedure for catalytic ethylation of benzaldehyde}

A solution of chiral aminoalcohol $(33 \mu \mathrm{mol})$ in $1.5 \mathrm{~mL}$ of dry toluene was placed at room temperature under nitrogen. $34 \mu \mathrm{L}$ of benzaldehyde $(0.33 \mathrm{mmol})$ then diethylzinc $(0.6 \mathrm{~mL}, 0.66 \mathrm{mmol}, 1.1 \mathrm{M}$ in toluene $)$ were added to the reaction mixture via syringe. The mixture was monitored by GC analysis until no more benzaldehyde was present. After completion, aqueous HCI $(1 \mathrm{~N}, 10 \mathrm{~mL})$ was added to quench the reaction. The mixture was extracted with $\mathrm{Et}_{2} \mathrm{O}$ and the organic layer was washed with brine, dried over $\mathrm{Na}_{2} \mathrm{SO}_{4}$ and evaporated under vacuum. After evaporation of the solvent, the crude oil was purified by column chromatography and the enantiomeric excess of 1-phenylpropanol was determined by chiral gas chromatography $\left(115^{\circ} \mathrm{C}, 0.75 \mathrm{bar}\right)$. The aminoalcohols can be recovered after an acidic wash of the organic layer, addition of $\mathrm{NaOH}$ to the aqueous layer, followed by extraction.

\section{Acknowledgments}

We thank the "Centre National de Recherche Scientifique" and the "Ministère de l'Éducation Nationale, de l'Enseignement Supérieur et de la Recherche" for financial support. We particularly thank Francine Agbossou-Niedercorn for her helpful comments.

\section{References}

1. Pu, L.; Yu, H.-B. Chem. Rev. 2001, 101, 757-824.

2. For recent articles see for examples: (a) Boyle, G.A.; Govender, T.; Kruger, H. G.; Maguire, G. E. Tetrahedron: Asymmetry 2004, 15, 2661-2666; (b) Scarpi, D.; Galbo, F. L.; Occhiato, E. G.; Guarna, A. Tetrahedron: Asymmetry 2004, 15, 1319-1324; (c) Ramón D. J.; Yus, M. Angew. Chem. Int. Ed. 2004, 43, 284-287; (d) Degni, S.; Wilén C.-E.; Leino, R. Tetrahedron: Asymmetry 2004, 15, 231-237; (e) Wu, K.-H.; Gau, H.-M. Organometallics 2004, 23, 580-588; (f) Joshi, S. N.; Malhotra, S. V. Tetrahedron: Asymmetry 2003, 14, 1763-1766; (g) Burguete, M. I.; Collado, M.; García-Verdugo, E.; Vicent, M. J.; Luis, S. V.; Graf von Keyserling, N.; Martens, J. Tetrahedron 2003, 59, 1797-1804.

3. Togni, A.; Hayashi, T. Ferrocenes, VCH: Weinheim, 1995.

4. For recent articles see for examples: (a) Bernardi, L.; Bonini, B. F.; Comes-Franchini, M.; Femoni, C.; Fochi, M.; Ricci, A Tetrahedron: Asymmetry 2004, 15, 1133-1140; (b) Arrayás, R. G.; Alonso, I.; Familiar, O.; Carretero, J. C. Organometallics 2004, 23, 1991-1996; (c) Curnow, O. J.; Fern, G. M.; Hamilton, M. L.; Zahl, A.; Van Eldik, R. Organometallics 2004, 23, 906-912; (d) Richards, C. J.; Locke, A. J. Tetrahedron: Asymmetry 1998, 9, 2377-2407.

5. For recent articles see for examples: (a) Tebben, L.; Kehr, G.; Fröhlich, R.; Erker, G. Synthesis 2004, 12, 1971-1976; (b) Cayuela, E.; Jalón, F. A.; Manzano, B. R.; Espino, G.; Weissensteiner, W.; Mereiter, K. J. Am. Chem. Soc. 2004, 126, 7049-7062; (c) (d) Liptau, P.; Neumann, M.; Erker, G.; Kehr, G.; Fröhlich, R.; Grimme, S. Organometallics 2004, 23, 21-25.

6. See for examples: (a) W. M.-C.; Wang, D.-K.; Zhu, Y.; Liu, L.-T.; Guo, Y.-F. Tetrahedron: Asymmetry 2004, 15, 1289-1294; (b) Jones, G.; Richards, C. J. Tetrahedron: Asymmetry 2004, 15, 653-664; (c) Li, M.; Zhu, X.-Z.; Yuan, K.; Cao, B.-X.; Hou, X.-L. Tetrahedron: Asymmetry 2004, 15, 219-222; (d) Fu, B.; Du, D.-M.; Wang, J. Tetrahedron: Asymmetry 2004, 15, 119-126; (e) Li, M.; Yuan, K.; Li, Y.-Y.; Cao, B.-X.; Sun, J.; Hou, X.-L. Tetrahedron: Asymmetry 2003, 14, 3347-3352; (f) Vilaplana, M. J.; Molina, P.; Arques, A.; Andrés, C.; Pedrosa, Tetrahedron: Asymmetry 2002, 13, 5-8; (g) Kim, T.-J.; Lee, H.-Y.; Ryu, E.-S.; Park, D.-K.; Cho, C. S.; Shim, S. C.; Jeong, J. H. J. Organomet. Chem. 2002, 649, 258-267; (h) Jones, G.; Butler, D. C. D.; Richards, C. J. Tet. Lett. 2000, 41, 9351-9354; (i) Arroyo, N.; Haslinger, U.; Mereiter, K.; Widhalm, M. Tetrahedron: Asymmetry 2000, 11, 4207-4219; (j) Gotov, B.; 
Toma, Š; Solčániová, E.; Cvengroš, J. Tetrahedron 2000, 56, 671-675; (k) Malézieux, B.; Andrés, R.; Gruselle, M.; Rager, M.-N.; Thorimbert, S. Tetrahedron: Asymmetry 1999, 10, 3253-3257; (1) Bolm, C.; Muñiz-Fernandez, K.; Seger, A.; Raabe, G.; Günther, K. J. Org. Chem. 1998, 63, 7860-7867.

7. (a) Atteke, C.; Ndong, J. M. M.; Aubouy, A.; Maciejewski, L.; Brocard, J.; Lebibi, J.; Deloron, P. J. Antimicrobial Chemotherapy, 2003, 51, 1021-1024. (b) Delhaes, L.; Biot, C.; Berry, L.; Delcourt, P.; Maciejewski, L.; Camus, D.; Brocard, J.; Dive, D. Chem. Bio. Chem. 2002, 3, 418-423.

8. (a) Delacroix, O.; Andriamihaja, B.; Picart-Goetgheluck, S.; Brocard, J. Tetrahedron 2004, 60, 1549-1556. (b) Bastin, S.; Ginj, M.; Brocard, J.; Pélinski, L.; Novogrocki, G. Tetrahedron: Asymmetry 2003, 14, 1701-1708. (c) Brunin, T.; Cabou, J.; Bastin, S.; Brocard, J.; Pélinski, L. Tetrahedron: Asymmetry 2002, 13, 1241-1243. (d) Delacroix, O.; Picart-Goetgheluck, S.; Maciejewski, L.; Brocard, J.; Nowogrocki, G. Synlett 2001, 1, 29-32.

9. (a) Cayuela, E. M.; Xiao, L.; Sturm, T.; Manzano, B. R.; Jalón, F. A.; Weissensteiner, W. Tetrahedron: Asymmetry 2000, 11, 861-869; (b) Tainturier, G.; Sok, K. C. Y.; Gautheron, B. C. R. Acad. Sc. Paris, Série C, 1973, 277, 1269-1270.

10. Rinehart, K. L.; Curby, R. J.; Gustafson, D. H.; Harrison, K. J.; Bozak, R. E.; Bublitz, D. E. J. Am. Chem. Soc. 1962, 84, $3263-3269$.

11. (a) Rinehart, K. L.; Curby, R. J. J. Am. Chem. Soc. 1957, 79, 3290-3291. (b) ibid 1957, 79, 3420-3424.

12. (a) Reeve, C. D.; Holt, R. A.; Rigby, S. R.; Hazell, K. Chimica Oggi/Chemistry Today 2001, 31-34; (b) Iglesias, L E; Rebolledo, F.; Gotor, V. Tetrahedron: Asymmetry, 2000, 11, 1047-1050; (c) Kijima, T.; Yaginuma, Y.; Izumi, T. J. Chem. Technol. Biotechnol. 1999, 74, 501-508.

13. (a) Chhor Y Sok, K.; Tainturier, G.; Gautheron, B. Tet. Lett. 1974, 25, 2207-2208; (b) Gokel, G. W.; Ugi, I. K. J. Chem. Educ., 1972, 49, 294-296.

14. The denominations $1 R, 1 S, 2 R$, and $2 S$ refer to the central chirality (near to the amino and to the hydroxy groups respectively) and the denominations $R_{\mathrm{p}}$ and $S_{\mathrm{p}}$ refer to the planar chirality. All the metallocene chiralities were determined according to the nomenclature of Cahn, Ingold and Prelog extended to planar chiralities by Schlögl: Schlögl, K. Topics in Stereochemistry 1967, 1, 39-91.

15. (a) Valkovich, P. B.; Gokel, G. W.; Ugi, I. K. Tetrahedron Lett. 1973, 31, 2947-2950. (b) Slocum, D. W.; Koonsvitsky, B. P.; Ernst, C. R. J. Organomet. Chem. 1972, 38, 125-132. (c) Slocum, D. W.; Engelmann, T. R.; Ernst, C.; Jennings, C. A.; Jones, W.; Koonsvitsky, B.; Lewis, J.; Shenkin, P. J. Chem. Educ. 1969, 46, 144-150.

16. Nicolosi, G.; Patti, A.; Morrone, R.; Piattelli, M. Tetrahedron: Asymmetry 1994, 5, 1275.

17. Sok, K. C. Y.; Tainturier, G.; Gautheron, B. J. Organomet. Chem., 1977, 132, 173.

18. Battelle, L. F.; Bau, R.; Gokel, G. W.; Oyakawa, R. T.; Ugi, I. K. J. Am. Chem. Soc. 1973, 95, 482-486.

19. A study on the determination of which stereocenter is responsible for the configuration of the phenylpropanol has been made. Manuscript in preparation.

20. Watanabe, M.; Araki, S.; Butsugan, Y. J. Org. Chem. 1991, 56, 2218-2224.

21. Uemura, M.; Miyake, R.; Nakayama, K.; Shiro, M.; Hayashi, Y. J. Org. Chem. 1993, 58, 1238-1244. 